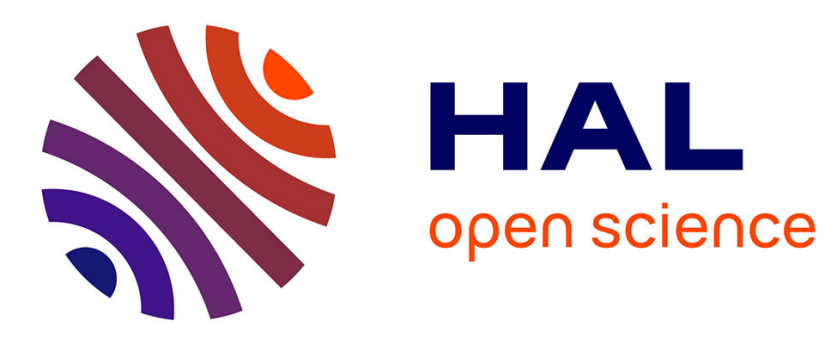

\title{
Industrial Action and Conflict Resolution in the New Member States
}

Christian Welz, Timo Kauppinen

\section{To cite this version:}

Christian Welz, Timo Kauppinen. Industrial Action and Conflict Resolution in the New Member States. European Journal of Industrial Relations, 2005, 11 (1), pp.91-105. 10.1177/0959680105050405 . hal-00570933

\section{HAL Id: hal-00570933 \\ https://hal.science/hal-00570933}

Submitted on 1 Mar 2011

HAL is a multi-disciplinary open access archive for the deposit and dissemination of scientific research documents, whether they are published or not. The documents may come from teaching and research institutions in France or abroad, or from public or private research centers.
L'archive ouverte pluridisciplinaire HAL, est destinée au dépôt et à la diffusion de documents scientifiques de niveau recherche, publiés ou non, émanant des établissements d'enseignement et de recherche français ou étrangers, des laboratoires publics ou privés. 


\title{
Christian Welz and Timo Kauppinen
}

European Foundation for the Improvement of Living and Working Conditions, Dublin, IRELAND

\section{Industrial Action and Conflict Resolution in the New Member States}

\begin{abstract}
With the historic enlargement of May 2004, the European Union faces new challenges. How the industrial relations systems of the new Member States respond to the challenges of accession, the single market and, eventually, EMU will play a crucial role in determining the ease of their assimilation within the enlarged Union. This article, based on a research and development project undertaken by the European Foundation for the Improvement of Living and Working Conditions, investigates and assesses a specific aspect of their industrial relations institutions, the mechanisms of extra-judicial conflict resolution. The existence of effective and efficient collective conflict resolution procedures and institutions strengthens social dialogue and the latter, again, plays an important role in the creation or reform of the existing dispute resolution procedures. Consequently, the article concludes that successful dispute resolution is directly correlated with the nature, scope and quality of collective bargaining and social dialogue in the new Member States.
\end{abstract}

\section{Introduction}

This article summarizes one theme from a broader study of industrial relations in the (then) acceding countries, undertaken by the European Foundation in Dublin. ${ }^{1}$ Its focus is the functioning of extra-judicial mechanisms of dispute resolution in the new Member States (NMS). We begin with an overview of the incidence of industrial disputes, and their legal status, in the NMS. The body of the article then surveys the institutions and procedures of conflict resolution. We conclude with a brief assessment of the implications for the future of industrial relations. 


\section{Industrial Action in the NMS}

Under the communist regimes which existed until 1990 in eight of the 10 NMS, strikes were a 'taboo issue' (EIRO, 2003a), but they have now become a legitimate and well rooted basic right of the trade unions and workers (EIRO, 2003b). In eight of the NMS (CY, CZ, HU, LT, LV, PL, $\mathrm{SK}, \mathrm{SI}$ ) the right to strike is indeed anchored in the national constitution. In the other two (EE, MT), strikes are regulated by national law. As Table 1 indicates, Cyprus has the broadest legal basis for strikes, with a regulatory framework based on the constitution, a national law and a collective agreement.

In discussing industrial action it is necessary to distinguish between strikes and lock-outs. The latter appear to be less comprehensively regulated. In five of the NMS the employers' right to lock-out is enacted in national statutes (CZ, EE, LV, MT, SK). In Cyprus the question is dealt with by a collective agreement. The other countries either have no legal basis for lock-outs (HU, PL, SI), or consider them an illegal form of action (LT) (Boda and Neumann, 2000; Borbély, 2001; Kocher, 2002).

The definiton of strikes appears to be rather similar in all NMS and is in line with international conventions (Novitz, 2003) and the national regulations applicable in the EU15. A typical definition is that in Estonia: 'an interruption of work on the initiative of employees or a federation of employees in order to achieve concessions from an employer or a federation of employers to lawful demands in labour matters'. A lock-out, by contrast, 'is an interruption of work on the initiative of an employer or an association of employers to achieve concessions from the employees or a federation of employees to lawful demands in labour matters'.

TABLE 1. Legal Basis for Industrial Action in the NMS

\begin{tabular}{lccc}
\hline & Right to strike & Right to lock-out & Year of enactment \\
\hline CY & C + L + CA & CA & 1960 \\
CZ & C + L & L & 1991 \\
EE & L & L & 1993 \\
HU & C + L & 0 & 1989 \\
LT & C + L & LO & 2002 \\
LV & C + L & L & $1998 / 2003$ \\
MT & L & L & 2002 \\
PL & C + L & 0 & 1991 \\
SK & C + L & L & 1991 \\
SI & C + L & 0 & 1990 \\
\hline
\end{tabular}

Notes: $\mathrm{C}=$ constitution; $\mathrm{CA}=$ collective agreement $\mathrm{L}=$ law $; 0=$ no legal basis; $\mathrm{LO}=$ prohibited by law. 
Practices and procedures, however, vary to a very large extent, consistent with the differing legal foundations indicated in Table 1. Many of the NMS have enacted regulations restricting the legality of strikes, as in EE, HU, LT, LV and SK. These provisions render strikes unlawful if they have not been preceded by a period of conflict resolution, violate the constitution, constitute a dispute of rights to be solved by the labour courts, endanger human life or the environment, etc. Some national statutes confirm the legality of solidarity strikes (CZ, $\mathrm{EE}, \mathrm{HU}, \mathrm{SK})$, and warning strikes are a legitimate means of industrial actions across most of the NMS (EE, HU, LT, PL) (Woolfson and Beck, 2002-3: 84).

It is a generally acknowledged principle that participation in a strike is voluntary (CZ, EE, HU, SK). Trade union representatives must therefore allow employees who do not wish to participate in a strike to enter and leave the workplace, and it is prohibited to impede their performance of work. They may not threaten them with any detriment, but may discuss with them the purpose of the strike. Thus, picketing is explicitly allowed in some of the NMS (LT, LV, SK), in others it is not regulated or used in practice (HU).

Most of the NMS (e.g. HU, LT, LV, PL, SK) ban, or at least impose certain limitations on, strike activity in essential services. The definition of such services of general interest varies considerably, however, between countries (European Commission [EC], 2003: 6-7). Strikes are most extensively banned from the armed forces, the judiciary as well as the internal security services. Limitations on the right to strike are also widely imposed with regard to public transport, electricity supply, telecommunications and other public utilities.

As Table 2 shows, the actual incidence of industrial action in recent years has been rather low, although it is very difficult to provide reliable, objective and comparable statistics. For some of the NMS (CZ, LV) no such data are available at all, while for others data on the number of working days lost (CZ, HU, LT, LV, SK) and/or the number of workers involved (CZ, EE, HU, LV) are lacking. In addition to these limitations, for methodological reasons it is difficult to evaluate the quantitative data that do exist: statistical definitions of strikes in the NMS, as in the EU15, vary enormously from one country to another. ${ }^{2}$

With these considerations in mind the following points are made very cautiously and only have the merit to reflect some preliminary, approximate trends. Out of the NMS with the most complete data sets (CY, EE, HU, LT, LV, MT, PL, SI, SK), in the period 1999-2001 Hungary, Poland (Kloc, 2002) and Cyprus have seen the most industrial action: on average 275,000 working days lost in Hungary, 72,000 in Poland and 11,000 in Cyprus per year. ${ }^{3}$ In the case of Hungary it must be noted that both the peak strike figure in 2000 and the enormous annual fluctuations stem 
TABLE 2. Working Days Lost in Strikes in the NMS

\begin{tabular}{lrrrrr}
\hline & 1999 & 2000 & 2001 & 2002 & $2003^{\mathrm{a}}$ \\
\hline CY $^{\mathrm{a}}$ & 26037 & 1136 & 4778 & 7019 & 4915 \\
EE $^{\mathrm{b}}$ & 1.4 & 1088 & 5 & 37 & 20192 \\
HU & 176375 & 636267 & 11676 & na & na \\
LTc & na & 3000 & 1700 & na & na \\
LV & na & 0 & 0 & na & na \\
MT & 1261 & 2564 & 2792 & 744 & 3305 \\
PL & 106900 & 74300 & 33400 & na & na \\
SI & 7507 & 4775 & 0 & 0 & na \\
SK & 0 & 0 & 0 & 0 & na \\
\hline
\end{tabular}

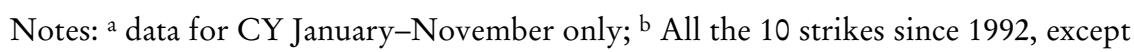
for 2003, have been one-hour warning strikes; the number of working days lost was calculated on the basis of number of strikers $\times 1 / 8$ working day; ${ }^{\mathrm{c}}$ Data from Woolfson and Beck (2004: 240).

Source: National reports. The formulae for calculating strikes, working days lost and participants may vary across countries. No data available for CZ.

from industrial action at one single company, the Hungarian State Railways (Magyar Államvasutak, MÁV) (EIRO, 2003a). Among the less strike-prone NMS, 4000 days were lost in Slovenia, 2000 in Malta, and 400 in Estonia, while virtually no strikes were recorded in Slovakia in these three years. It was only in 2003 that the first real strikes surfaced in Estonia and Slovakia, in the latter mainly in the railway sector. In Estonia the Estonian Employees' Union Federation (TALO) called a one day strike involving more that 20,000 workers on 4 December 2003, which is considered to be the first real strike, in contrast to previous warning strikes and other protest actions, since Estonia gained independence: this strike had been officially authorized by the public conciliator (EIRObserver, 2004).

In some of the NMS, austere economic reforms entailing losses in real income rendered the socio-economic fabric rather fragile during the period of transition to a market economy and thus were a fertile ground for industrial action in the early 1990s (Iankova and Turner, 2004: 88). As a general trend, however, industrial action is on the decline since the mid1990s in the NMS: this is also true for Poland, the transition economy which witnessed the most widespread industrial action in the course of the 1990s (Pollert, 1999: 156). In view of the latest developments of industrial protests in Lithuania, however, some scholars argue that the days of labour quiescence in the NMS may be over. High levels of material deprivation, the pursuit of neoliberal policies of deregulation and repressive anti-union legislation are the essential corrobation of this thesis 
(Woolfson and Beck, 2004: 250-1). In Slovenia strike rates peaked in 1992 after the huge system transformation from 1988 but then declined. Conflicting reasons have been offered for this fall; Stanojevic (2003b) emphasizes the consolidation of a system of 'political exchange' within which Slovenian unions were able under a sympathetic political regime to achieve many of their objectives without the need for militant action. In other transition economies, a sharp decline in strike action after the initial period of economic and political transformation has been attributed to such factors as the retreat of the state from the economy, growing unemployment, fragmentation of the economy, fragmentation and weakening of trade unions, reduced inclination and capacity for industrial action and a general unpopularity of strikes since they were prohibited in Soviet times (Dovydeniene, 1999: 26; Stanojevic, 2003a: 28).

A feature of most NMS is that large-scale strikes tend to occur in the public services and public utilities, as a means by which workers try to put pressure on the government; in the private sector, by contrast, workplace-level industrial action predominates. The main categories of workers involved in strikes are thus public employees (especially teachers, nurses, doctors and judges), and in addition those working in large industrial enterprises, traditional heavy industries and 'privileged workers ... in close contact with Western workers, and able to use comparators' such as airline pilots, cabin attendants, and workers in multinational companies such as Škoda (Martin and Cristescu-Martin, 2003: 506-7)). Strikes are also frequent in sectors undergoing fundamental restructuring, for example, mining and energy in Estonia and textiles in Slovenia (EC, 2002b: 100-1).

\section{Conflict Resolution in the NMS}

The main focus of this article is on collective conflicts, in other words disputes that generally relate to collective agreements rather than the entitlements of individual employees. We adopt a definition stemming from Spanish procedural law: a collective conflict is one that 'affects the general interest of a generic group of workers and that deals with the enforcement or the interpretation of a statutory regulation, collective bargaining agreement or a corporate decision or practice' (Valdes Dal-Ré, 2002, 2003: 47). Since some EU15 countries (e.g. DK, SE) limit the scope of collective disputes to those involving collective agreements only, the boundary between collective and individual conflicts is somewhat opaque.

Collective disputes can be subdivided into two categories. The first involves 'conflicts of rights', or disputes on the interpretation of the content of an existing collective agreement. The regulatory framework of 
most of the NMS provides for judicial procedures for resolving such disputes (as is also the case in the majority of EU15 countries). An exception to this rule is Cyprus, where all collective conflicts are dealt with by the Ministry of Labour.

The second type of dispute, 'conflicts of interest', arises in the course of attempts to conclude a new collective agreement or to renew an existing collective agreement at the end of its period of currency. In this case, conflict resolution mechanisms normally involve extra-judicial procedures such as conciliation, mediation and arbitration. These provide the main focus of the present survey (Gladstone, 2001; Goldman, 2001).

As in the EU15 (Valdés Dal-Ré, 2003), the main conflict resolution mechanisms in the NMS consist of the classic triad: conciliation, mediation, arbitration (ETUC/INFOPOINT, 2002). All three have in common that a third party is asked to intervene in order to resolve a conflict between the two sides of industry; it is then the nature and degree of the intervention that distinguish the three different procedures.

Conciliation is the 'softest' form of intervention by a third party, who acts only as a facilitator by maintaining the two-way flow of information between the conflicting parties and encouraging a rapprochement between their antagonistic positions. Mediation goes a step further: this mechanism allows the third party to take the initiative in tabling proposals directed towards a resolution of the conflict (Casale, 1998; de Roo and Jagtenberg, 1994: 24-31; Valdés Dal-Ré, 2003: 51). The dividing line between conciliation and mediation is a narrow one and in some countries they are treated as identical procedures (Thaler and Bernstein, 2003: 14). In a number of NMS either the difference is not acknowledged (Malta) or the boundaries between the two mechanisms overlap (Estonia, Slovakia, Slovenia). Arbitration is at the other end of the scale of intensity of third-party involvement: it is for the arbitrator to decide how to solve the conflict. The character of arbitration itself can vary, in terms of whether the parties are bound (by law or by prior agreement) to submit certain disputes to arbitration, and whether they are bound to accept the arbitrator's award. In its least binding forms, arbitration is little stronger than mediation.

The ultimate goal of all procedures of extra-judicial conflict resolution is the maintenance of labour peace. Conflict avoidance is invested with all the characteristics of a public good: no third person has an incentive to provide the good, the service is public in nature, its consumption cannot be controlled. In a nutshell, labour peace 'helps to ensure a smooth running, efficient and growing economy, to be enjoyed by all of society, not just those who invest their money in the conciliation services that help to maintain labour peace' (Thaler and Bernstein, 2003: 6).

Given the large variety of national systems of conflict resolution, and the potential overlap between mechanisms it is not straightforward to 
TABLE 3. Predominant Procedures for Conflict Resolution ${ }^{a}$

\begin{tabular}{lcccccc}
\hline & Conciliation & Mediation & Arbitration & Other & $\begin{array}{c}\text { Voluntary/ } \\
\text { statutory }\end{array}$ & $\begin{array}{c}\text { Institutional } \\
\text { basis }\end{array}$ \\
\hline CY & 0 & $\mathbf{x x}$ & $\mathrm{x}$ & $\mathrm{V}$ & $\mathrm{a}$ \\
CZ & 0 & $\mathrm{x}$ & $\mathrm{x}$ & $\mathrm{S}$ & $\mathrm{d} / \mathrm{e}$ \\
EE & $\mathrm{x}$ & $\mathbf{x x}$ & 0 & $\mathrm{~S}$ & $\mathrm{a}$ \\
HU & $\mathrm{x}$ & $\mathrm{x}$ & $\mathrm{x}$ & $\mathrm{S}$ & $\mathrm{b}$ \\
LT & $\mathrm{x}$ & $\mathrm{x}$ & $\mathrm{x}$ & & $\mathrm{S}$ & $\mathrm{e}$ \\
LV & $\mathrm{x}$ & $\mathrm{x}$ & $\mathrm{x}$ & & $\mathrm{S}$ & $\mathrm{e}$ \\
MTc & $\mathrm{x}$ & $\mathbf{x x}$ & $\mathrm{x}$ & & $\mathrm{S}$ & $\mathrm{a}$ \\
PL & & $\mathrm{x}$ & $\mathrm{x}$ & $\mathrm{x}$ & $\mathrm{V} / \mathrm{S}$ & $\mathrm{e}$ \\
SK & $\mathrm{x}$ & $\mathbf{x} x$ & $\mathrm{x}$ & & $\mathrm{S}$ & $\mathrm{d} / \mathrm{e}$ \\
SI & & $\mathbf{x x}$ & $\mathrm{x}$ & & $\mathrm{V}$ & $\mathrm{e}$ \\
\hline
\end{tabular}

Notes: ${ }^{\mathrm{a}} \mathbf{x x}=$ dominant; $\mathrm{x}=$ exists, but not dominant; $0=$ weak or non existent; ${ }^{\mathrm{b}} \mathrm{a}=$ a public institution/official within the labour administration; $b=$ independent public conflict resolution agency; $\mathrm{c}=$ an independent private conflict resolution agency; $\mathrm{d}=$ person independent of the labour administration, but chosen from a list of experts kept by the Ministry of Labour; $\mathrm{e}=$ voluntary and autonomous conflict resolution bodies set up by the social partners; ${ }^{c}$ no distinction is made between conciliation and mediation; $\mathrm{d}$ autonomous negotiations between the two sides of industry and 'goodwill missions'.

assess the predominant procedure in specific countries; but Table 3 provides some indication of the main institutions in each NMS. The frequent form of conflict resolution is 'mediation', which is used for dispute settlement purposes in all ten NMS: in five countries it is also identified by the national experts as the principal form of conflict resolution. Conciliation is much less used, in only six of the countries. Arbitration as a final means of conflict resolution is to be found in all NMS except Estonia.

\section{Basis of Extra-judicial Conflict Resolution}

As in the EU15, the institutions and procedures of conflict resolution in the NMS originate in and are governed by either national legislation or voluntary agreements between employers and unions. As Table 3 indicates, most of the systems in the NMS stem have a statutory basis. The exceptions are Slovenia, Cyprus, with the non-statutory provisions of the Industrial Relations Code, and Poland where the mediation and arbitration procedures are, at least partially, rooted in voluntary collective agreements. This seems to be in stark contrast with the EU15, 'where the 
resolution methods for collective disputes are established and regulated by typically bargaining-based instruments such as inter-professional agreements and collective agreements' (Valdés Dal-Ré, 2003: 32-3). An explanation for the predominance of statutory procedures may be sought in the greater heterogeneity and fragmentation, and thus relative weakness of the social partners in NMS States (Kauppinen and Welz, 2003: 86). ${ }^{4}$

\section{Institutions and Processes}

Most of the legal and industrial relations systems in the NMS distinguish between disputes of rights and of interest. The two are normally regulated differently: the former are to be settled in court, while the latter are to resolved through extra-judicial conflict resolution mechanisms. Only in the case of the latter are strikes and lock-outs permitted. In the NMS, as in the EU15, the actors have recourse to a wide range of different institutions and processes to resolve collective disputes of interest.

The first type involves a public institution or official within the labour administration. Such an arrangement is to be found in Belgium (social conciliators), Finland (national and district conciliators) (European Foundation, 2004a: 21) and Denmark (Statens Forligsinstitution) (Stokke and Thörnqvist, 2001: 247). In Estonia, the institution of Public Conciliator was established in the second half of 1995; he or she is appointed for a term of three years by the government on the basis of agreement between the Ministry of Social Affairs and central federations of employers and federations of employees. There are also 24 local conciliators. In Malta, too, the government performs a pivotal role in conflict resolution through the Department of Industrial and Employment Relations (DIER). It usually offers its conciliation services, following consultation with the Minister, as soon as there are indications of a potential industrial conflict. The present Director describes his role as one of 'trust building and confidentiality'. A similar internal resolution mechanism also exists in Cyprus.

A second mechanism involves an independent public conflict resolution agency, which is external to the labour administration, but supplied with organizational, financial and human resources by the public authorities. This procedure is quite widespread in the EU15, existing for example in the UK (ACAS), Ireland (Labour Relations Commission) and Sweden (National Mediation Office) (Elvander, 2002: 206). In the NMS a comparable agency exists only in Hungary: the Labour Mediation and Arbitration Service (Munkaügyi Közvetitoôi és Döntóbirói Szolgálat, MKDSZ) was established through an agreement between the government and social partners in 1996. It is based at the Ministry of Labour and Employment, with a full-time director and secretary, and maintains a 
register of (currently 63) experienced mediators and arbitrators. The parties involved in a dispute normally use its services, though this is voluntary. The MKDSZ overseen by the tripartite National Council for the Reconciliation of Interests, but this does not limit the independence of its day-to-day operations (www.fmm.gov.hu/mkdsz).

A third procedure involves an independent private conflict resolution agency. In the EU15 such a mechanism exists only in Spain and Greece. The Spanish Servicio Interconfederal de Mediación y Arbitraje (SIMA, www.fsima.es) was created as a private foundation by the social partners through their joint Agreement on Alternative Labour Dispute Resolution (Acuerdo sobre Solución Extrajudicial de Conflictos, ASEC) of 1996. Though a private agency, SIMA is subsidized by public funds, thus rendering its services free of charge to the social partners. A similar procedure also exists in Greece: the Mediation and Arbitration Service (Organismós Mesolávisis ke Dietisías, OMED) is an independent agency established in 1992 and governed by a tripartite board. Its creation, on the basis of a law of 1990 designed to advance free collective bargaining, has been described as 'ground-breaking' (Yannakourou and Koukoules, 2003: 203). However, nothing of this kind exists in the NMS.

A fourth method of mediation involves a person independent of the labour administration, but chosen from a list of experts kept by the Ministry of Labour. This procedure is not widespread in the EU15. In the NMS, only the Czech Republic and Slovakia use a corresponding mechanism. According to the Czech Collective Bargaining Act, if the parties to a dispute cannot agree on a mediator from the official list, the Minister may make an appointment at the request of either of the parties.

In a fifth type of procedure, disputes are handled by voluntary, autonomous conflict resolution bodies set up by the social partners. In the EU15, such an approach can be found in Germany (Kocher, 2002: 663-5), for example. In the NMS, this model is followed in Latvia and Lithuania, in so-called conciliation commissions or via mediators chosen by the two parties to a conflict. A similar voluntary mechanism also exists in Poland and Slovenia, and represents the first stage of dispute resolution in the Czech Republic and Slovakia, where - if this fails - the Ministry of Labour appoints a mediator chosen from a pre-existing list.

Finally, no conflict resolution procedures and institutions may exist. In a few EU15 countries (for example, The Netherlands) there are no specific regulations or institutions for the resolution of labour disputes. This tends to reflect the strength of broader corporatist arrangements between the social partners. Such industrial relations structures are traditionally associated with a low incidence of industrial action. Similar preconditions do not exist in the NMS (Elvander, 2002: 208-9). 


\section{The Incidence of Extra-judicial Conflict Resolution}

Unfortunately, data on the incidence of conciliation, mediation and arbitration in the NMS are even more scarce than statistics on industrial action. However, aggregate figures for 1999-2001 show that the largest number of disputes referred to conflict resolution was in Cyprus (587 cases), followed by Poland (383) and Malta (237). Far fewer cases were reported from the Czech Republic (86), Estonia (80) and Hungary (25).

It is interesting to compare the figures on cases referred to dispute resolution procedures with the reported incidence of strikes. In Hungary the numbers are almost identical: 25 cases, 24 strikes). In all other NMS there are far more cases referred for settlement than actual stoppages: in Estonia, 80 as against only three strikes; in Malta, 237 (as against 41); in Cyprus, 587 (compared to 52). The only NMS with the opposite relationship is Poland, where 975 strikes were recorded in the years 1999-2001, but only 383 cases referred to mediation. ${ }^{5}$ Further research based and more reliable data would, however, be required in order to draw sound conclusions on the efficiency and effectiveness of the national conflict resolution systems.

\section{Conclusion: Relative Labour Quiescence and Disparate Approaches to Conflict Resolution}

Our survey has shown that in the majority of NMS, the right to strike is anchored in the constitution, and elsewhere is recognised by law. Lockouts are less comprehensively regulated. In the detailed regulation of industrial conflict, practice and procedure varies considerably between one NMS and another.

Data on the incidence of stoppages are deficient and provide little basis for comparative analysis. In those NMS with the most complete datasets (CY, EE, HU, LT, LV, MT, PL, SI, SK), Hungary, Poland and Cyprus have seen the most industrial action in the period 1999-2001. Even here it seems clear that, as in the EU15, industrial action in recent years has been infrequent (Crowley, 2003). Taking into account these rather low figures, it is certainly fair to conclude that 'the number and depth of collective actions in their first years of transition has not reflected the gravity of the social situation and the burden of the transition for the workers as well as the population' (EC, 2002b: 100).

The most frequent form of conflict resolution in the NMS is mediation. Conciliation is much less used, but arbitration as the final stage of conflict resolution is to be found in all NMS except Estonia. In terms of institutional arrangements, two mechanisms predominate: voluntary and autonomous conflict resolution organizations established by the social 
partners, and internal administraive procedures within the labour ministries. An independent public conflict resolution agency comparable to ACAS in the UK or the Labour Relations Commission in Ireland only exists in Hungary.

The existence of effective and efficient extra-judicial collective conflict resolution procedures and institutions strengthens social dialogueand the latter, in turn, plays an important role in the creation or reform of dispute resolution procedures (Vaughan-Whitehead, 2000). Effective and efficient national systems are the necessary prerequisite for any conceivable creation of a conflict resolution mechanism at EU level (Iankova and Turner, 2004; Schömann, 2002: 704; Valdés Dal-Ré, 2002).

\section{NOTES}

1 This study of 'Conflict Resolution Mechanisms in the Acceding Countries (AC)' derived from previous projects on the 'Impact of EMU on Industrial Relations', 'Europeanisation of Industrial Relations' and 'Social Dialogue and EMU in the Acceding Countries' (European Foundation, 2000, 2002a, 2003) which shaped to a large extent the present project design. The objective was to gather employers, trade unions, national governments and researchers from the new Member States in order to investigate and assess how social dialogue could best be utilized to adapt, refine and if necessary reform the existing mechanisms of extra-judicial conflict resolution. The European Foundation carried out this research and development project in cooperation with the Swedish Government 'Work Life and EU Enlargement' programme. The national researchers contributing to the project were: CY: Orestis Messios; CZ: Lenka Korcova; EE: Kaia Philips and Raoul Eamets; HU: Beáta Nacsa and András Tóth; LT: Grazina Gruzdiene; LV: Daiga Ermsone; MT: Edward Zammit; PL: Zbigniew Haijn; SK: Ludovit Cziria; SI: Metka Penko-Natlacen. The individual country reports are available at http://www.eurofound.eu.int/publications/ Industrial\%20Relations.htm. For the full synthesis report see European Foundation, Social Dialogue and Conflict Resolution in the Acceding Countries, Luxembourg, OOPEC, 2004.

2 For example, countries vary in terms of the minimum duration and numbers involved for a stoppage to be included in the official statistics, whether political stoppages are included, and whether workers indirectly affected by a stoppage are counted. Similar differences exist, however, across the whole of Europe (Franzosi, 1989).

3 A breakdown of the strike incidence per 1000 workers would have been more informative, but unfortunately these data were not available via the national reports. However, Employment in Europe reports total employment in 2000 of 279,000 in Cyprus, 3,807,000 in Hungary and $14,518,000$ in Poland. On this basis, Hungary appears the most strike-prone of the NMS. For other aggregated data on working days lost per 1000 workers see Funk and Lesch (2004: 8). 
4 Beyond the geographical scope of this report, it is interesting to note that one of the most important accomplishments of tripartism in Bulgaria is seen as the Law on the Settlement of Collective Labour Disputes adopted by the National Assembly in 1990.

5 This may reflect an exceptional situation in Poland: the strike figures for 1999 were extraordinarily high (920 cases of industrial action).

\section{REFERENCES}

Boda, D. and Neumann, L. (2000) 'Social Dialogue in Hungary and its Influence on EU Accession', Transfer 6(3): 416-33.

Borbély, S. (2001) 'Industrial Disputes in Hungary', South-East Europe Review (1): 51-72.

Casale, G. (1998) The Settlement of Labour Disputes in Central and Eastern Europe. Budapest: ILO.

Crowley, S. (2002) Explaining Labour Quiescence in Post-communist Europe: Historical Legacies and Comparative Perspective. Harvard: Center for European Studies and Eastern Europe, working paper 55.

Dovydeniene, R. (1999) Trade Union Responses to Globalisation in Lithuania, Labour and Society Programme, DP/111. Geneva: ILO.

EIRO (2003a) Labour Dispute Settlement in Four Central and Eastern European Countries. Dublin: European Foundation.

http://www.eiro.eurofound.eu.int/2003/01/study/TN0301101S.html.

EIRO (2003b) Developments in Industrial Action 1998-2002. Dublin: European Foundation. http://www.eiro.eurofound.eu.int/ 2003/03/update/tn0303104u.html.

EIRO (2004) Industrial Relations in the EU, Japan and USA 2002. Dublin: European Foundation.

Elvander, N. (2002) 'The New Swedish Regime for Collective Bargaining and Conflict Resolution: A Comparative Perspective', European Journal of Industrial Relations 8(2): 197-216.

European Commission (EC) (2002a) Communication from the Commission. The European Social Dialogue. A Force for Innovation and Change, COM (2002) 341 final.

EC (2002b) Industrial Relations in Europe 2002. Luxembourg.

EC (2003) Green Paper on Services of General Interest, COM(2003) 270 final.

European Foundation (2000) The Impact of Economic and Monetary Union on Industrial Relations: A Sectoral and Company View. Luxembourg: OOPEC.

European Foundation (2002a) The Europeanisation of Industrial Relations in a Global Perspective: A Literature Review. Luxembourg: OOPEC.

European Foundation (2002b) Industrial relations in the EU Member States and the Candidate Countries. Luxembourg: OOPEC.

European Foundation (2003) Social Dialogue and EMU in the Acceding Countries. Luxembourg: OOPEC.

European Foundation (2004a) European Employment and Industrial Relations Glossary: Finland. Luxembourg: OOPEC. 
European Foundation (2004b) Social Dialogue and Conflict Resolution in the Acceding Countries. Luxembourg: OOPEC.

European Foundation/European Commission (2004) Industrial Relations Developments in Europe 2003. Luxembourg: OOPEC.

ETUC/INFOPOINT (2002) Resolving Industrial Disputes in Accession Country Companies. Brussels: ETUI.

Franzosi, R. (1989) 'One Hundred Years of Strike Statistics. Methodological and Theoretical Issues in Quantitative Strike Statistics', Industrial and Labor Relations Review 42(3): 348-62.

Funk, Lothar and Lesch, H. (2004) 'Arbeitsbeziehungen in Mittel- und Osteuropa', iw-trends 1: 8.

Gladstone, A. (2001) 'Settlement of Disputes over Rights', in R. Blanpain and C. Engels (eds) Comparative Labour Law and Industrial Relations in Industrialized Market Economies, 7th edn, pp. 629-54. The Hague: Kluwer.

Goldman, A.L. (2001) 'Settlement of Disputes over Interests', in R. Blanpain and C. Engels (eds) Comparative Labour Law and Industrial Relations in Industrialized Market Economies, 7th edn, pp. 655-79. The Hague: Kluwer.

Gradev, G. (2003) 'CEE Social Dialogue and Trade Unions in the Enlargement Context - Developing or Diverging?’, in H. Keller, M. Weiss, O. Jacobi and R. Hoffmann (eds) European Integration as a Social Experiment in a Globalized World, pp. 131-47. Düsseldorf: Hans Böckler Stiftung.

Hajn, Z. (2002) 'Collective Labour Agreements and Contracts of Employment in Polish Labour Law', in B. Lewaszkiewicz-Petrykowska (ed.), Rapport polonais présenté au Seizième Congrès International de Droit Comparé, Brisbane. Wydawnictwo Uniwersytetu Lódzkiego.

Hála, J. et al. (2002) Development of Social Dialogue in the Czech Republic. Prague: RILSA.

Héthy, L. (2001) Social Dialogue and the Expanding World. The Decade of Tripartism in Hungary and in Central and Eastern Europe 1988-99. Brussels: ETUI.

Jasarevic, S. (2003) 'Labour Dispute Settlement in Serbia', South-East Europe Review for Labour and Social Affairs 6(3): 31-9.

Kauppinen, T. and Welz, C. (2003) 'Social Dialogue and Economic and Monetary Union (EMU) in the Acceding Countries (AC): An Overview', in European Foundation (ed.), Social Dialogue and EMU in the Acceding Countries, pp. 1-51. Luxembourg: OOPEC.

Kittel, B. (2002) EMU, EU Enlargement, and the European Social Model: Trends, Challenges, and Questions. Cologne: Max-Planck-Institut für Gesellschaftsforschung, working paper 02/01.

Kloc, K. (2002) Labour Conflicts and Strikes in Poland in the 1990s and Methods of Solving Them. Paper given at the ILO 'First Conference of Central and Eastern European Labour Mediators and Arbitrators', 14-21 June 2002. Budapest, mimeo.

Kocher, E. (2002) 'The Regulation of Conflicts in the German Industrial Relations System: Legal and Extra-legal Institutions and Procedures', Transfer 8(4): 654-69.

Martin, R. and Cristescu-Martin, A. (2003) 'Employment Relations in Central 
and Eastern Europe 2002: Towards EU Accession', Industrial Relations Journal 34(5): 498-509.

Meardi, G. (2002) 'The Trojan Horse for the Americanization of Europe? Polish Industrial Relations Towards the EU', European Journal of Industrial Relations 8(1): 77-99.

Monger, J. (2003) 'International Comparisons of Labour Disputes in 2000', Labour Market Trends 111(1): 19-27.

Novitz, T. (2003) International and European Protection of the Right to Strike. Oxford: Oxford University Press.

Pollert, A. (1999) Transformation at Work in the New Market Economies of Central and Eastern Europe. London: SAGE.

Rebhahn, R. (2003) 'Collective Labour Law in a Comparative Perspective. Collective Agreements, Settlement of Disputes and Workers Participation (Part I)', International Journal of Comparative Labour Law and Industrial Relations 19(3): 271-95.

Rebhahn, R. (2004) 'Collective Labour Law in a Comparative Perspective (Part II)', International Journal of Comparative Labour Law and Industrial Relations, 20(1): 107-32.

Roo, A., de and Jagtenberg, R. (1994) Settling Labour Disputes in Europe. The Hague, Kluwer.

Rychly, L. and Pritzer, R. (2003), Social Dialogue at National Level in the EU Accession Countries. Geneva: ILO.

Schömann, I. (2002) 'Alternative Dispute Resolution Procedures in Labour Issues: Towards an EU Mechanism?', Transfer 8(4): 701-7.

Schroeder, W. (2003) 'Arbeitsbeziehungen in Mittelosteuropa', WSI-Mitteilungen 56(1): 51-9.

Shalev, M. (1992) 'The Resurgence of Labour Quiescence', in M. Regini (ed.), The Future of Labour Movements, pp. 102-32. London: SAGE.

SIMA (2001) Segundo Acuerdo sobre Solución Extrajudicial de Conflictos Laborales (ASEC-II). Madrid: SIMA.

Stanojević, M. (2003a) 'Formation of the Slovenian Strike Pattern: the Strike Wave and Industrial Rigidities', South-East Europe Review (3): 17-30.

Stanojević, M. (2003) 'Workers' Power in Transition Economies: The Cases of Serbia and Slovenia', European Journal of Industrial Relations 9(3): 283-301.

Stokke, T.A. (2002) 'Conflict regulation in the Nordic Countries', Transfer 8(4): 670-87.

Stokke, T.A. and Thörnqvist, Ch. (2001) 'Strikes and Collective Bargaining in the Nordic Countries', European Journal of Industrial Relations 7(3): 245-67.

Thaler, D. and Bernstein, A. (2003) Strengthening Governmental Conciliaton Institutions. A practitioner's handbook. Washington, DC: Federal Mediation and Conciliation Service. URL: www.apelclmg.org

Valdés Dal-Ré, F. (2002a) 'Conciliación, mediación y arbitraje en los países de la Unión Europea’, Relaciones Laborales: Revista Crítica de Teoría y Práctica 18(18): 17-38.

Valdés Dal-Ré, F. (2002b) 'Bases para la implantación de un sistema no jurisdicional de conflictos de trabajo de dimensión europea (I y II)', Relaciones Laborales: Revista Crítica de Teoría y Práctica 18(8-9): 1-10.

Valdés Dal-Ré, F., ed. (2003) Labour Conciliation, Mediation and Arbitration in 
the European Union Countries. Madrid: Ministerio de Trabajo y Asuntos Sociales.

Vaughan-Whitehead, D. (2000) 'Social Dialogue in EU Enlargement: Acquis and Responsibities', Transfer 6(3): 387-98.

Vaughan-Whitehead, D. (2003) EU Enlargement Versus Social Europe. The Uncertain Future of the European Social Model. Geneva: International Labour Office.

Welz, C. and Kauppinen, T. (2004) 'The Role of Social Dialogue in the Acceding Countries during the Preparatory Phase for Economic and Monetary Union (EMU)', International Journal of Comparative Labour Law and Industrial Relations 20(4): 583-603.

Welz, C. and Kauppinen, T. (2004a) 'Social Dialogue and Conflict Resolution in the Acceding Countries', European Foundation, Luxembourg: OOPEC.

Woolfson, C. and Beck, M. (2002-3) 'The Right to Strike. Labour Market Liberalization and the New Labor Code in Pre-accession Lithuania', Review of Central and East European Law 28(1): 77-102.

Woolfson, C. and Beck, M. (2004) 'The End of Labour Quiescence? Industrial Unrest in Contemporary Lithuania', International Journal of Comparative Labour Law and Industrial Relations 20(2): 227-51

Yannakourou, M. and Koukoules, G. (2003) 'Labour Conciliation, Mediation and Arbitration in Greece’, in Fernando Valdés Dal-Ré (ed.) Labour Conciliation, Mediation and Arbitration in the European Union Countries, pp. 195-229. Madrid: Ministerio de Trabajo y Asuntos Sociales.

CHRISTIAN WELZ and TIMO KAUPPINEN are research managers at the European Foundation for the Improvement of Living and Working Conditions. ADDRESS: European Foundation, Wyattville Road, Loughlinstown, Dublin 18, Ireland. [e-mail: christian.welz@eurofound.eu.int] 